\title{
Nursing theories in the conceptual expansion of good practices in nursing
}

\author{
Teorias de enfermagem na ampliação conceitual de boas práticas de enfermagem \\ Teorías de enfermería para la ampliación conceptual de buenas prácticas en enfermería
}

\section{Marcos Antônio Gomes Brandão" ORCID: 0000-0002-8368-8343}

Alba Lucia Bottura Leite de Barros' ORCID: 0000-0003-2691-3492

Cândida Caniçali Primo"' ORCID: 0000-0001-5141-2898

Gisele Saraiva Bispo' ORCID: 0000-0001-6649-8778

Rafael Oliveira Pitta Lopes" ORCID: 0000-0002-9178-8280

'Universidade Federal de São Paulo. São Paulo-SP, Brasil.

"Universidade Federal do Rio de Janeiro,

Escola de Enfermagem Anna Nery. Rio de Janeiro-RJ, Brasil.

"'Universidade Federal do Espírito Santo. Vitória-ES, Brasil.

How to cite this article:

Brandão MAG, Barros ALBL, Primo CC, Bispo GS, Lopes ROP. Nursing theories in the conceptual expansion of nursing practices. Rev Bras Enferm. 2019;72(2):577-81. doi: http://dx.doi.org/ 10.1590/0034-7167-2018-0395

Corresponding Author: Marcos Antônio Gomes Brandão E-mail: marcosbrandao@ufrj.br

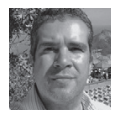

Submission: 07-01-2018

Approval: 08-24-2018

\section{ABSTRACT}

Objective: To discuss the contribution of nursing theories in the conceptual expansion of good practices in the area for the construction of the unified health system (Sistema Único de Saúde - SUS). Method: Theoretical production of reflection, based on the neomodern framework of philosophy of science. Results: The knowledge and political, social and epistemological commitments of nursing are discussed, highlighting the relationship of the theories with good practices for the construction and application of knowledge in the area in the context of the Brazilian health care system. Reflection on how middle-range theories can help in solving dichotomies between discipline, theory, practice, producers and consumers of knowledge is made. Conclusion: Original reflections on the contributions of disciplinary and professional knowledge of nursing theories to the creation of SUS are presented, defending a creation through the academy-service partnership, in which the theories start being incorporated into a new concept of nursing practices aligned to neomodern principles of science.

Descriptors: Theoretical Models; Nursing Theory; Nursing Care; Unified Health System; Practice Patterns, Nurses.

\section{RESUMO}

Objetivo: Discutir a contribuição das teorias de enfermagem na ampliação conceitual de boas práticas da área para a construção do Sistema Único de Saúde (SUS). Método: Produção teórica de reflexão, sustentada no referencial neomodernista da filosofia da ciência. Resultados: Aborda-se o conhecimento e os compromissos políticos, epistemológicos e sociais da enfermagem, destacando as relações das teorias com as boas práticas na construção e aplicação dos conhecimentos da área no âmbito do sistema de saúde brasileiro. Reflete-se como as teorias de médio alcance podem auxiliar na resolução de dicotomias entre disciplina, teoria, prática, produtores e consumidores do conhecimento. Conclusão: Apresentam-se reflexões originais de contribuições do conhecimento disciplinar e profissional das teorias de enfermagem para a construção do SUS, defendendo-se uma construção pela parceria academia-serviço, na qual as teorias passam a ser incorporadas a uma nova conceituação de boas práticas de enfermagem alinhada a princípios neomodernistas da ciência.

Descritores: Modelos Teóricos; Teoria de Enfermagem; Cuidados de Enfermagem; Sistema Único de Saúde; Padrões de Prática em Enfermagem.

\section{RESUMEN}

Objetivo: Discutir la contribución de las teorías de enfermería a la ampliación conceptual de buenas prácticas del área en la construcción del Sistema Único de Salud (SUS). Método: Estudio teórico de reflexión, con base en el referencial neomodernista de la filosofía de la ciencia. Resultados: Se discuten el conocimiento y los compromisos políticos, epistemológicos y sociales de la enfermería, destacándose las relaciones entre la teoría y las buenas prácticas en la construcción y aplicación de los conocimientos del área en el ámbito del sistema de salud brasileño. Se reflexiona sobre cómo las teorías de medio alcance pueden contribuir a la resolución de dicotomías entre disciplina, teoría, práctica, productores y consumidores de conocimientos. Conclusión: Se estableció una mirada original a las contribuciones del conocimiento disciplinario y profesional de las teorías de enfermería para la construcción del SUS, defendiendo una construcción por la asociación academia-servicio, en la cual las teorías pasan a incorporarse desde una nueva conceptualización de las buenas prácticas de enfermería con los principios neomodernistas de la ciencia.

Descriptores: Modelos Teóricos; Teoría de Enfermería; Atención de Enfermería; Sistema Único de Salud; Pautas de la Práctica en Enfermería. 


\section{INTRODUCTION}

Technological and knowledge advances in the health field that result in new drugs, diagnostic methods and treatments have been observed, in addition to being realized changes in the pattern of population ageing and in its life style, impacting their work, social security and everyday life as a whole. The emergence of new diseases, resurgence of old ones and significant increase in chronic illness conditions have also been occurring. Increasingly, the understanding of the complexity of reality strengthens, which establishes new relationships, producing recursive causalities between knowledge and the transformation of human, environment and society. In the social context, such relational changes interfere with health care and with the formation of complex adaptive health systems whose components interact in unexpected ways in unpredictable relations, requiring participants to continuously adapt and learn ${ }^{(1)}$.

All the changes have created challenges for the agents involved in health care. Specifically for nursing, the search for good practices is a central and multidimensional challenge. Good practices can be regarded as the set of techniques, processes and activities that are understood as the best available to perform a certain task, being consistent with the values, goals and evidences of health promotion and conscious of the environment in which they are developed ${ }^{(2)}$. The definitions for the expression "best practices" are not clearly adapted for application in care; however, this lack does not appear to be actually able to subtract your importance. In the health field, good practices require theoretical basis, environmental consciousness and observance of ethical principles, values and beliefs of the providers and consumers of the actions and the services related to them ${ }^{(3)}$. Joining practice and theory would be, therefore, essential to adopt them.

In addition to the technical dimension, the concept of good practices requires the incorporation of the theoretical dimension to describe, explain, predict or prescribe contextual realities. Theory and practice go hand in hand and are supported by evidences from scientific research. Nursing theories can bring benefits for patients' health care due to the ability to produce consistent explanations, descriptions, predictions and prescriptions, which would support the profession in the work in complex contexts such as the Brazilian unified health system (SUS). However, in the country, this potential of nursing theories has not been much valued.

The philosophical school of logical positivism proposed a unified science, free of values, and a theorization developed by using mathematics and symbolic logic. Positivism, by prioritizing empiricism, ends up strengthening the separations between thought and action. If the expression "good practices" is exclusively considered through positive logic, it can fall into a practical and decontextualized utilitarianism. Meanwhile, neomodern perspective brings a different comprehension by preserving the importance of theory, without, however, disassociate it from practice and from the agents that operate in the reality ${ }^{(4)}$. Such philosophical inclinations reinforce the need of expanding the concept of good practices to maintain the union of theoretical and practical dimensions.

In Brazil, SUS is the main health care system, providing most of the health care services for population; it is also the main context of practice of nursing. However, the restricted use of theories in this field to produce good practices, or derived from these practices, tends to determine a lack of theoretical tools that would be useful for presenting descriptive and explanatory elements about the insertion of the profession in the health system. Moreover, we need more recent publications presenting reflections or results of studies to align nursing theories with universal health systems, to promote, thus, the use of these theories in health care and nursing in the context of SUS. Both the potentials and the gaps verified in knowledge interact to justify the dissemination of reflections on the subject.

\section{OBJECTIVE}

To discuss the contribution of nursing theories to the conceptual expansion of good practices in nursing for the creation of SUS.

\section{METHOD}

Theoretical production of reflection, based on the neomodern framework of philosophy of science. The neomodern perspective was chosen due to its aim to overcome the Modernist practices that separate the esthetical experiences of the scientific theorization and its theorists from the context of discovery. Neomodernism applied to health understands scientific theory as a cooperative process involving the scientist, the technician (health and nursing professionals) and the user as knowledge partners, taking the role of producers, not only of strict consumers of the knowledge produced by others ${ }^{(4)}$. The assumptions of the framework clearly converge to the principles and philosophies of SUS, as well as are aligned with the experiences of continuous development of the system.

The preparatory procedures for the construction of the reflection were: selection of the central theme for evaluation and discussion and selection of national and foreign publications aligned with the theme and with the framework of theorists who presented substantive constructs, forming a corpus of texts producing results capable of allowing discussion. Considering the format normative restrictions for this article, ten publications indispensable to reflect on the theme were selected as references, and the others were only kept in the authors' original material.

\section{RESULTS}

The reading of the bibliographic materials that subsidized the reflexive procedures allowed the construction of lines of arguments based on the neomodernist framework to represent the results of this reflection, being better presented in the form of reflective discussion.

The reflective discussion addresses aspects of the contributions of nursing theories to the constitution of good practices in the field and its alignment with a universal health system, particularly with SUS. Finally, it shows a definition for good practices in nursing that incorporates theories as a constituent element.

\section{REFLECTIVE DISCUSSION}

Although Florence cited the difference between nursing and medical knowledge, until the early 20th century, professional actions were still strongly influenced by a traditional philosophy of science, based on the biomedical model, with emphasis on 
action $^{(5)}$. By grounding the practice only in the biomedical model, nurses neither expand nor sediment their specific professional action (professional advance), neither generate nor incorporate their own knowledge (disciplinary advance), especially through nursing theories.

Knowledge has been the continuous object of study and debate within the nursing discipline. As a dynamic element, nursing knowledge has accompanied the changes in the traditions of the philosophy of science, surpassing modernism, with its experimentation and questioning of dogmas, and moving on to postmodernism, with its criticisms of fundacionism, essentialism and historical-social realism, and nowadays, of the neomodernism, which proposes integrating philosophical approaches or places itself between modernism and postmodernism, transcending the bipolar dispute ${ }^{(4)}$.

Social and political commitments mark nursing work, even when clinic and technique are emphasized. Training through ethical-philosophical apparatus, articulated with citizen and political participation and other social actions, strongly supports the practice of nursing professionals and, as such, is emphasized by professional associations in the field.

In the United States, the American Nurses Association (ANA) proposes that nurses have active and lasting leadership in determining public policies of a social nature, applying nursing knowledge to decisions related to: organization, supply and financing of qualified health care; public health provision; expansion of nursing and health knowledge, with appropriate application of technology; expansion of health resources and of its policies; health policy planning and regulation; and obligations under extreme conditions ${ }^{(6)}$

The Brazilian Association of Nursing (Associação Brasileira de Enfermagem - ABEn) has defended the training of nursing and health professionals committed to SUS principles - among them, universality. It points out the relevance of nursing in facing challenges related to integral, safe and good care, as well as it encourages actions to strengthen, improve and discuss the financing and the federal pact supporting SUS ${ }^{(7)}$.

The construction of nursing knowledge to influence health systems starts from the recognition of the complexity of this field and must be guided by a multifaceted understanding of the nature of knowledge that goes beyond the purely technical vision.

The theory-practice alignment can be verified, for example, in the theoretical model dealing with secondary care in the health care system, which incorporated the idea of the best practices. The theoretical model had the peculiarity of having been elaborated together with managers, professionals and patients of Emergency Care Units (Unidades de Pronto Atendimento - UPA), of the Mobile Emergency Care Service (Serviço de Atendimento Móvel de Urgência - Samu), of polyclinics, of the Dental Specialties Center (Centro de Especialidades Odontológicas - CEO) and of the Center for Psychosocial Care (Centro de Atenção Psicossocial - Caps), linked to SUS ${ }^{(2)}$.

Given the successful experiences that align practice-theory and knowledge producers-agents, abandoning the dichotomous belief of doctor researchers as the only producers of knowledge and of "practical" nurses as strict consumers is necessary ${ }^{(4)}$. Nursing theories can play a fundamental role in building bridges between practitioners and academicians - however, this is not only a question of producing new nursing theories, but also a matter of generating and validating nursing theories from the perspective of a non-dichotomized knowledge. In fact, a process of producing "along with the other" is required, so that knowledge can be contextualized and sensitive to the dimensional multiplicity of health care, especially in its universal systems.

In this article, theories are adopted as bases for reflections on how the disciplinary knowledge and the professional practice of nursing, expressed by and in the theories of the field, could contribute to the Brazilian universal health system, especially through its relations with the expansion of the concept of nursing good practices. The so-called neomodernist "dogmas" of the philosophy of science are applied to them aiming at overcoming a narrow interpretation of the concept and construct of "nursing theory". The neomodernist dogmas to be applied in this article are: a new empiricism to encourage the use of new methods, instruments and technologies to explain the knowledge produced; a new epistemology to educate professionals to use the various patterns of knowledge to produce knowledge; a critical realism to recognize subliminal pattern, capacity for self-organization, institution, humanism, spirituality and potential for empowerment; the valorization of differences and continuous criticism of oppression; recognition of universal and shared principles and of individual singularity and local truths; the defense of the maintenance of open, dynamic and contextually relevant metanarratives, theories and philosophies ${ }^{(4)}$.

The authors of this article recognize that nursing theories are not free of values. As formulations of authors, the theories carry worldviews, descriptions, explanations, and prescriptions of realities compatible with the group, time, and culture that molded them. Theories are flawed, have tendencies and are limitedly useful in a given context or phenomenon. However, this perspective is exactly the factor allowing the defense of the alignment of nursing theories with the practice of nursing professionals to pursue the goal of achieving good or better practices, becoming their use an instrument (theoretical) to explain the knowledge produced by the profession in the context of SUS strongly recommended.

Some nursing theories, especially in the categories of big theories, may have idealized worldviews that are confronted with others more supported by the empirical and social field, such as Marxian theories. On the opposite side, dialectical and praxis-oriented theories can robustly preserve the theory-practice dialectical unity, such as the Theory of Praxis Intervention of Nursing in Collective Health (Teoria de Intervenção Práxica da Enfermagem em Saúde Coletiva - Tipesc) ${ }^{(8)}$. The characteristics of Tipesc are in harmony with the neomodernist thought, being an example of how nursing theories can contribute to the conceptual expansion of the expression "good practice", preserving a continuity between theory and practice.

Professional nursing not only contributes to the advancement of SUS but also is constantly modified by its principles, characteristics and values, in a dynamic, historical and socially engaged way. Thus, nursing theories in fact must be developed and tested in articulation with the health system, to contribute as a relevant type of disciplinary and professional knowledge. To be relevant, nursing theories also need to meet criteria that justify them in pragmatics. 
Firstly, they must be applicable in the professional practice. One recognizes that big nursing theories are difficult to be used in the empirical field of care, thus they must work primarily as philosophies or world views. However, middle-range theory can best meet the demands of professional health and nursing care, considering its ability to operate exactly between the abstract level of the big theories and the empirical level of the testing and construction of hypotheses in reality.

Nursing theories need to be useful and compatible with a multidisciplinary and multiprofessional health context. This seems to be achieved when we reflect that many middle-range theories have been developed from others from other fields. In fact, theories and conceptual models from other fields seem to be the most common sources for the development of those looked upon as nursing theories. Thus, this discipline has developed and tested theories articulated with multidisciplinary and transdisciplinary knowledge in the interests of the health field, without putting a corporate defense of its knowledge in a prominent position. Arguing that the neomodernist dogma of the maintenance of open, dynamic and contextually relevant metanarratives, theories and philosophies has been met is possible.

Nursing theories need to be relevant to health care. Core concepts, such as adaptation, comfort and transition, were strongly structured, described and developed as constructs of nursing theories and are examples already incorporated into health care. In fact, the concern of the nursing discipline with the analysis and development of concepts to serve as basis for its theories and practice has been remarkable.

SUS is the main environment for the creation of new knowledge, models, theories and technologies for health in Brazil, being the most relevant context for its application as well. Several aspects in grand and middle-range nursing theories are strongly compatible with doctrinal orientations from the system. Professionals can use methods and instruments that develop and analyze theories that include grounded theory, clinical reasoning, research-action, clinical conceptual structures, and structured reflection ${ }^{(9)}$. Such integrative resources and methods can probably collaborate to the development and analysis of good practices in care. Gowin's V diagram can be used as a structured reflection tool, encouraging the recognition of the integration of theoretical and practical/ methodological domains of health knowledge ${ }^{(10)}$ and promoting the development or analysis of good practices from the neomodernist integrative perspective of theory-practice.

Nursing theories can both represent structures for the development and testing of technologies and knowledge and be the soft-hard technologies indispensable for consolidating nursing and health good practices. A great potential of correlation exists between nursing theories and SUS, such as: the development of models of relations between specific nursing interventions (professional) and lines of care (multiprofessional); the proposition of definitions of humanization policies, considering the knowledge about nature and the aspects of human care present in nursing theories; and the redefinition of nursing concepts based on the users' perceptions.

Attempts to incorporate nonexclusively empirical knowledge patterns are vital for the completeness of health care, as can be seen in the Brazilian National Policy on Integrative and
Complementary Practices (Política Nacional de Práticas Integrativas e Complementares- PNPIC). Nursing research may offer evidences for the proposition of new inductively developed middle-range theories. These theories would be able to provide essential instrumental constructs and knowledge for the completeness, such as empirical models that align the concepts of "territory" in basic attention with the environment constructs derived from nursing theories and models.

Nursing theories have contributed to the development of a solid knowledge base, organizing the phenomenal world of the field based on metaparadigmatic concepts. Human experience (individual and collective) should be considered for a true contribution from nursing theories, observing issues related to humanism, spirituality, capacity for self-organization and empowerment ${ }^{(4)}$. In this regard, the conformation of the Brazilian health system has promoted the approximation of society as participant and active agent, even considering the structural and contextual difficulties in creating legitimate interaction environments marked by horizontal dialogue.

Nursing theories can allow the valuation of differences because they tend to express the profession dimension, sharing viewpoints from the feminist epistemology, searching for ways to maximize equality and promote freedom from oppression ${ }^{(4)}$. The issues of power, gender and class relation in nursing and health, and the mechanisms of oppression and empowerment of nurses and patients are topics of interest for middle-range nursing theories. From this perspective, those, for example, derived from critical approaches to reality can contribute to the welfare of the whole system by preserving an indispensable disciplinary perspective, while awakening a historical, political and social debate that considers the context in which good practices are forged.

Assuming that the integrality of SUS can be achieved with the persistence of professional hegemonies that try to delay the development of the health system is inconceivable. In this view, nursing theories can preserve the disciplinary perspective differentiating the service and can construct best practices, which point out the different characteristics, but also open the way to actions and thoughts articulated with the other health actors.

Overcoming the dichotomy between action and thought, theory and practice may enable incorporating nursing theories into the care of the field in the context of SUS. In Reed's viewpoint, the neomodernist thought addresses the integration of practice and theory in nursing knowledge. A neomodernist basis cannot permit dichotomous conceptions of thought and action. In the nursing discipline, theory exists in the philosophical and empirical context and in the theoretical dimension, with a production path whose bases are practice and research ${ }^{(4)}$.

The application of the neomodernist perspective to good practices allows arguing that any set of techniques, processes or activities available to perform a given task can only maintain consistency with values, objectives, evidences of health promotion and understanding of the environment by preserving the connection with theory. By overcoming the positivist and post-positivist limits on the term "theory", understanding it from the perspective of process and product is possible. The theory can be viewed as a process of interacting with the patient in practice or as a gift that emerges from the encounter in nursing 
care, and the theorization by the nurse is a way of appreciating this gift received ${ }^{(9)}$.

Thus, the conceptual expansion of "good practices" is explained, understanding them, in nursing, as an interrelated and inseparable set of theories, techniques, processes and activities that are presented as the best options available to perform the care of the field, being compatible with knowledge, values, contexts, environments, objectives and disciplinary and transdisciplinary evidences in the interests of health.

\section{CONCLUSION}

This article brings original reflections on the contributions of the disciplinary and professional knowledge expressed in the nursing theories to the creation of a health system, highlighting the case of SUS. Using a neomodernist perspective, the ideas present in the considerations propose the overcoming of dichotomies between theory and practice, disciplinary and multidisciplinary, universality and singularity.

One argues that the middle-range nursing theories have a greater potential of application in the SUS context. Hence, the authors sought to exemplify themes and proposals that may be in a relevant research agenda in nursing theories for this system. Nevertheless, one admits the challenge of formulating and applying middle-range theories in Brazilian nursing. There is a strong demand for the operational knowledge of nursing theories and of how their use can improve the professional practice and the care provided for patients, which would favor the criticism and expansion of the reflections presented in this article.

It presents a redefinition of the concept of nursing good practices, incorporating, as their constituent elements, neomodernist principles, theories and knowledge from which they derive.

\section{REFERENCES}

1. World Health Organization-WHO. Global strategic directions for strengthening nursing and midwifery 2016-2020[Internet]. Geneva: WHO; 2016[cited 2018 May 30]. Available from: http://www.who.int/hrh/nursing_midwifery/global-strategic-midwifery2016-2020.pdf?ua=1

2. Erdmann AL, Andrade SR, Mello ALSF, Drago LC. Secondary Health Care: best practices in the health services network. Rev Latino-Am Enfermagem [Internet]. 2013 [cited 2018 Nov 26];21(9):131-9. Available from: http://www.scielo.br/pdf/rlae/v21nspe/17.pdf

3. Guerrero P, Mello ALSF, Andrade SR, Erdmann AL. User embracement as a good practice in primary health care. Texto Contexto Enferm [Internet]. 2013 [cited 2018 Nov 26];22(1):132-40. Available from: http://www.scielo.br/pdf/tce/v22n1/16.pdf

4. Reed PG. Commentary on neomodernism and evidence-based nursing: Implications for the production of nursing knowledge. Nurs Outlook [Internet]. 2006 [cited 2018 Nov 26];54(1):36-8. Available from: https://www.nursingoutlook.org/article/S0029-6554(05)00003-5/ fulltext

5. Madureira VSF. Nursing knowledge. Rev Bras Enferm [Internet]. 2004 [cited 2018 Nov 26];57(3):357-60. Available from: http://www.scielo.br/ pdf/reben/v57n3/a21v57n3.pdf

6. Alligood MR, Miles JM. Nursing knowledge and health policy in process. Nurs Sci Q [Internet]. 2012[cited 2018 Nov 26];24(1):7-8. Available from: https://journals.sagepub.com/doi/10.1177/0894318410389069

7. Alvarez AM. The Brazilian Association of Nursing in the uncompromising defense of the Brazilian Unified Health System. Rev Bras Enferm [Internet]. 2015 [cited 2018 Nov 26];68(2):185-6. Available from: http://www.scielo.br/pdf/reben/v68n2/en_0034-7167-reben-68-02-0185.pdf

8. Egry EY, Fonseca RMGS, Oliveira MAC, Bertolozzi MR. Nursing in collective health: reinterpretation of objective reality by the praxis action. Rev Bras Enferm [Internet]. 2018 [cited 2018 Nov 26];71(Suppl-1):710-5. Available from: http://www.scielo.br/pdf/reben/v71s1/0034-7167reben-71-s1-0710.pdf

9. Brandão MAG, Denadai W, Primo CC, Lopes ROP, Peixoto MAP.V diagram as a tool for analytical integrationof theoretical, conceptual, and methodological knowledge in health care. Rev Gaúcha Enferm [Internet]. 2018 [cited 2018 Nov 26];39:e2017-0015. Available from: http:// www.scielo.br/pdf/rgenf/v39/en_1983-1447-rgenf-39-01-e2017-0015.pdf

10. Reed PG, Shearer NBC. Nursing knowledge and theory innovation. 2nd ed. New York: Springer; 2017. 